\title{
Effects of vacuum packaging on the physical quality of minimally processed potatoes
}

\author{
Ada M. C. N. Rocha, Emilie C. Coulon and Alcina M. M. B. Morais \\ Escola Superior de Biotecnologia, Universidade Católica Portuguesa, Rua Dr António Bernardino de Almeida, 4200-072 \\ Porto, Portugal
}

\begin{abstract}
Correspondence:

A. M. M. B. Morais,

Universidade Católica

Portuguesa, Rua Dr António

Bernardino de Almeida,

4200-072 Porto, Portugal.

Tel: +351225580050

Fax: +351225090351

E-mail: amorais@esb.ucp.pt
\end{abstract}

Keywords:

convenience, IV gamma,

minimally processed, potato,

quality, vacuum

\section{Introduction}

Potatoes are a crop of ancient origin. They were first cultivated in South America (Andes Mountains) and introduced to Europe in the 16th century. They gained recognition as an inexpensive and nutritious food in the 18 th century and are now among the 10 major food crops of the world grown in 140 countries (Macrae \& Robinson 1993). They are the most grown vegetable in the world and the fourth most important crop, next to wheat, maize and rice in global tonnage (Macrae \& Robinson 1993).

It is well established that the consumption of vegetables is good for health (Krause \& Mahan 1985). Potatoes are a good source of carbohydrate, protein, vitamins and minerals. They have a slightly lower energy content $(335 \mathrm{~kJ}$ per $100 \mathrm{~g})$ than other roots, tubers, cereals and legumes, but this is advantageous in overcoming the problem of obesity in the developed world (Macrae \& Robinson 1993). On the other hand, large quantities of potato have been consumed in developing countries to meet their populations' daily energy needs. It has been calculated that $100 \mathrm{~g}$ of potato can supply $5-7 \%$ of the daily energy and $10-12 \%$ of the daily protein needs of children aged $1-5$ years (Macrae \& Robinson 1993). One hundred grams of potato can supply $3-6 \%$ of the daily, human (adult) protein requirement (depending upon sex and body weight), and one medium-sized potato provides $15 \mathrm{mg}$ of vitamin C, which is about $20 \%$ of the recommended allowance $(60 \mathrm{mg}$ ) per person and per day (RDA 1989).

Consumption of potatoes with the skin increases the dietary fibre intake. It is also a valuable food for those who suffer from excessive acidity of the stomach as it has an alkaline reaction (Macrae \& Robinson 1993). Potato fat content is too low to have any nutritional significance, but it does contribute towards palatability. The potato also provides most of the trace elements needed to maintain good health such as iron, potassium, phosphorus, magnesium, sulphur, copper, zinc and manganese which are the most important mineral present. One hundred grams of cooked potato contribute $250 \mathrm{mg}$ of potassium and can supply $6 \%$ and $12 \%$ of the daily iron requirement for children and adults, respectively (Johnson et al. 1968; Macrae \& Robinson 1993).

Fruits and vegetables have improved the human diet for centuries, enriching both its nutrition and sensory properties. But as consumers become more health conscious in their food choices, they also have less time to prepare healthy meals. As a result, minimally processed (MP) products have become an important sector of the food industry because of their 'fresh-like' qualities, convenience and speed with which meals can be prepared. 
An increasing number of people are consuming at least one meal out of the home. Food service operations often have to prepare large quantities of food, such as potatoes, vegetables, onions and carrots, in a short period of time. Often, they have to prepare (peel and cut) these products the day before consumption which can lead to excessive losses of soluble and sensitive nutrients (Laurila et al. 1998). These products, when supplied to the consumer/food service operation in a convenient format, peeled, cored or sliced in prepared packages, with 'fresh-like' qualities and ready for preparation/consumption, comprise in a new category of products called 'Minimally Processed' (MP). Other terms used to refer to MP products are 'lightly processed', 'partially processed', 'fresh processed' and 'pre prepared' (Rocha \& Morais 2001).

To be acceptable to consumers/food service operations, MP products must have a 'fresh' appearance, be of consistent quality and be reasonably free of defects. Physical damage or wounding caused by preparation increases the rate of biochemical reactions responsible for changes in colour (including browning), flavour, texture and nutritional quality (such as vitamin loss). The use of vacuum packaging is a promising alternative to chemical treatment, for maintaining the quality of MP vegetables.

Potatoes are extremely sensitive to enzymatic browning. The storage life of peeled or cut raw potatoes is limited by the onset of enzymatic browning at cut surfaces. The discoloration results from the polyphenoloxidase (PPO)-catalized oxidation of phenolic compound to quinone and their subsequent condensation to darkcoloured pigment called melanine (Langdon 1987; O’Beirne \& Ballantyne 1987; Sapers \& Miller 1992; Chassery \& Gormley 1994; Ahevenainen et al. 1998; Laurila et al. 1998). It is generally assumed that minimal processing operations cause disruption of compartmentalization, allowing substrates and enzymes (oxidases) to come in contact (Brecht 1995). Because it is generally accepted that PPO is the enzyme mainly responsible for browning, an increase in PPO activity after peeling and cutting would be expected (Lattanzio et al. 1994).

When the cellular compartmentalization is disrupted, phenolic compounds may be involved in both enzymatic and non-enzymatic browning reactions. In the former case, the oxidation of phenolic substrates is catalysed by PPO activity and the quinones formed can take part in secondary reactions, bringing about the formation of dark secondary products (Laurila et al. 1998; Reyes-Moreno et al. 2001). In the latter case, the common cause of darkening is attributable to the interactions between phenols and heavy metals, such as iron, which yield coloured complexes (Lattanzio et al. 1994). Vamos-Vigyàzò (1981) indicated that the rate of discoloration following mechanical injury is first higher, then decreases, and finally drops to zero. This conforms with enzyme inactivation and with the pattern of decrease in substrate content observed after bruising (Whitaker 1994; Rocha \& Morais 2001).

The origins of controlled/modified atmosphere vacuum food preservation are generally attributed to the research of Kidd and West in the early years of 20th century (Brody 1989). Vacuum packaging, which removes the air from food packages, is now widely used to extend food shelf life and the quality of processed product (Hintlian \& Hotchkiss 1986; Brody 1989; Gorris \& Peppelenbos 1992; Varoquaux \& Nguyen 1994). The use of vacuum packaging greatly inhibits the progress of oxidative reactions and inhibits the growth of aerobic microorganisms, which generally lead to deterioration of foodstuffs during storage (Martens 1995).

A knowledge of the nutritional and physical impacts of minimal processing operations on these products will be an advantage for producers in that they will possess information to create new markets, and for the consumer/food service operation, because they will have a new range of highly convenient products. In this study, the physical quality of MP potatoes ('Désirée' variety) stored for 7 days in vacuum packaging was evaluated.

\section{Materials and methods}

\section{Plant material}

'Désirée' potatoes which have a yellow flesh and a purple skin were grown in Portugal. Samples were supplied ready processed and packed by the firm 'Interbatata'. Potatoes were automatically peeled by abrasion, manually selected for visual defects, immediately washed and vacuum-packed. Potatoes were left whole in order for them to be used in a variety of different ways for cooking.

\section{Treatment and storage conditions}

Potatoes were packed under vacuum with a Multivac machine (vacuum of $1 \mathrm{mBar}$ during $10 \mathrm{~s}$ ) and stored in a cold room at $4-6^{\circ} \mathrm{C}$. Bags consisted of an outer polyamide (PA) layer and an inner polyethylene (PE) layer with properties in Table 1 . The PA gives mechanical strength and impermeability to $\mathrm{O}_{2}$ and other gases. PE is co-extruded for its water and vapour impermeability (Martens 1995).

Each day of storage a pouch was removed from refrigeration, opened and the potatoes placed in salted water $(0.9 \% \mathrm{NaCL})$ in order to avoid leaching of sol- 
Table 1 Physical properties of packaging film

Package film of 'Desirée'

Film thickness

$\mathrm{CO}_{2}$ permeability $\left(23^{\circ} \mathrm{C} / 50 \% \mathrm{RH}\right)$

$\mathrm{O}_{2}$ permeability $\left(23^{\circ} \mathrm{C} / 50 \% \mathrm{RH}\right)$

$\mathrm{H}_{2} \mathrm{O}$ permeability $\left(23^{\circ} \mathrm{C} / 50 \% \mathrm{RH}\right)$

PA, polyamide; PE, polyethylene; $\mathrm{RH}$, relative humidity.

uble nutrients until used in experiments. Potatoes were evaluated for weight loss, firmness, colour, PPO activity, enzymatic activity, total phenolic compound, titratable acidity, $\mathrm{pH}$, soluble solids content and reducing sugars.

\section{Weight loss}

Weight loss was calculated from the weight of five peeled potatoes per replicate measured before and after storage. The weight loss was expressed as a percentage of initial fresh weight. The dry weight was determined by drying a weighed aliquot of potato slices at $85^{\circ} \mathrm{C}$ for 5 days and re-weighing.

\section{Firmness}

Firmness (6 mm deformation) was measured at four different parts of five potatoes (two measurements at the midpoint and two measurements at the top and bottom of the potatoes) with an Instron Universal Testing Instrument (Model 1132, Instron Corp., Canton, $\mathrm{OH}, \mathrm{USA}$ ) for each time of storage. A 100 Newton (N) load cell was used for firmness determination of the potatoes. Cross-head speed was $10 \mathrm{~mm} / \mathrm{min}$. This speed was selected considering that potatoes would have to be cooked before eating and therefore what was important is that the chosen speed allowed relative changes of firmness of raw potatoes to be measured. A 7-mm diameter convex tip Magness-Taylor type probe was used. This test measured individual tuber firmness based on the resistance of the potato flesh to deformation by the probe (Kader 1982).

\section{Colour assessment}

Cut potato surface colour was measured with a handheld tristimulus reflectance colorimeter (Model CR200b, Minolta Corp., Ramsey, NJ, USA). Colour was recorded using the CIE-L*a*b* uniform colour space (CIE-Lab), where $\mathrm{L}^{*}$ indicates lightness, $\mathrm{a}$ * indicates chromaticity on a green $(-)$ to red $(+)$ axis, and $b^{*}$ chromaticity on a blue (-) to yellow $(+)$ axis. A decrease of $\mathrm{L}^{*}$ value and an increase of $\mathrm{a}^{*}$ value is a useful indicator of darkening during storage (Mastrocola \& Lerici 1991; Monsalve-Gonzalez et al. 1993; Rocha \& Morais 2001).

\section{PPO activity}

Extraction procedure of PPO was described by Rocha $\&$ Morais (2001). The potato samples (20 g) were homogenized with $0.2 \mathrm{M}$ pH 6.5 sodium phosphate buffer (extraction buffer) plus $2 \%$ polyvinilpirrolidone (PVPP) for 3 min using a blender jar with external ice bath, with $1 \mathrm{~min}$ intervals after each minute of homogenization. The homogenates were centrifuged at $4^{\circ} \mathrm{C}$ for $30 \mathrm{~min}$ at 16000 r.p.m. (Sorvall RC-5C, Instruments Dupont, refrigerated super speed centrifuge). The supernatant was filtered through cheesecloth and its volume determined for enzymatic activity assay.

\section{Enzymatic activity}

Enzyme activity was assayed by measuring the rate of increase in absorbance at $420 \mathrm{~nm}$ in a Perkin-Elmer Lambda 15 UV/VIS spectrophotometer. The reaction mixture contained $3.0 \mathrm{~mL}$ of catechol solution $(2.2 \%)$, freshly prepared in $0.05 \mathrm{M}$ sodium phosphate buffer at $\mathrm{pH} 6.5$, and a fixed quantity of enzyme. The reference cuvette contained only the substrate solution. The unit for the enzymatic activity was defined as a change of 0.001 in the absorbance value under the conditions of the assay.

\section{Total phenolic compound}

Each replicate of potatoes was crushed and filtered through cheesecloth. Total phenolic content was measured using the Folin-Ciocalteau reagent (Folin \& Ciocalteau 1927; Singleton \& Rossi 1965). Aliquots $(0.50 \mathrm{~mL})$ of clear potato juice were diluted in $9.5 \mathrm{~mL}$ distilled water, and $4 \mathrm{~mL}$ of a diluted Folin-Ciocalteau reagent ( $1 \mathrm{~mL}$ plus $9 \mathrm{~mL}$ distilled water) was added to $1 \mathrm{~mL}$ of the resulting solution. In the time period between $30 \mathrm{~s}$ after the addition of Folin-Ciocalteau reagent, but before $8 \mathrm{~min}$ elapsed, $4 \mathrm{~mL}$ of sodium carbonate solution was added. After $1 \mathrm{~h}$ at $30^{\circ} \mathrm{C}$ plus $1 \mathrm{~h}$ at $0^{\circ} \mathrm{C}$, the absorbance of the solution was measured at $760 \mathrm{~nm}$. Dopamine was used to obtain the standard curve $(0.5-5.0 \mu \mathrm{g}$ dopamine $/ \mathrm{mL})$, and the concentration of phenols was calculated directly from that curve, because the standard and samples were treated identically. Total phenols were expressed as $\mu \mathrm{g}$ dopamine/100 $\mathrm{g}$ of potato fresh weight.

\section{Titratable acidity and $\mathrm{pH}$}

Aliquots $(10 \mathrm{~mL})$ of potato juice were diluted with $40 \mathrm{~mL}$ of distilled water and titrated with $0.1 \mathrm{~N}$ $\mathrm{NaOH}$, beyond $\mathrm{pH}=8.2$. This potentiometric titration was performed with a $\mathrm{pH}$ meter Crison, Model Micro pH 2002 (Crison Instrument, S.A., Barcelona, Spain). The results were calculated as a percentage of malic acid $[(\mathrm{ml} \mathrm{NaOH} * 0.1 \mathrm{~N} / \mathrm{mL}$ sample titrated $) * 100]$. 
The $\mathrm{pH}$ was measured in the juice of the crushed potato before $\mathrm{pH}$ determination, using a $\mathrm{pH}$ meter Crison, Model Micro pH 2002 (Crison Instrument) which had been previously standardized to $\mathrm{pH} 4$ and $\mathrm{pH} 7$, and a xerolyt electrod Ingold Lot 406-MG-DXK$57 / 25$.

\section{Soluble solids content}

The soluble solids content of non-diluted juice from crushed potatoes was determined at $20^{\circ} \mathrm{C}$ (room temperature) with a hand refractometer, Model Atago ATC1. Results were expressed in ${ }^{\circ} \mathrm{BRIX}\left(1^{\circ} \mathrm{BRIX}=1 \mathrm{~g}\right.$ soluble solid/100 g solution).

\section{Reducing sugars}

Each replicate of potatoes was crushed and filtered through a cheesecloth. Reducing sugar was measured using the dinitrosalicylic (DNS) reagent. First, aliquots $(1 \mathrm{~mL})$ of clear potato juice were diluted in $49 \mathrm{~mL}$ distilled water. About $900 \mu \mathrm{L}$ of this solution was pipetted into a test tube, followed by addition of $100 \mu \mathrm{L}$ of $\mathrm{NaOH} 0.1 \mathrm{M}$ and $1 \mathrm{~mL}$ of DNS reagent. Then, the test tubes were placed in a boiling water bath $\left(120^{\circ} \mathrm{C}\right)$ for $5 \mathrm{~min}$, and $4 \mathrm{~mL}$ of distilled water was added. The absorbance of the solution was measured at $540 \mathrm{~nm}$. Glucose was used to obtain the standard curve $(0.1-0.6 \mathrm{~g} / \mathrm{L})$, and the concentration of reducing sugar was calculated directly from that curve, because the standard and samples were treated identically. Reducing sugars were expressed as g sugars $/ 100 \mathrm{~g}$ of potato fresh weight.

\section{Control}

Two controls were performed by storing vacuumpacked potatoes at room temperature and also by storing peeled potatoes packed in perforated bags under refrigeration $\left(6^{\circ} \mathrm{C}\right)$.

\section{Results and discussion}

\section{Weight loss and firmness}

'Désirée' potato dry weight was $22 \%$. The weight loss after 7 days of storage was about $3 \%$ (Fig. 1) which is considered quite low.

This probably results from the vacuum package: moist food did not dry out because there is no air to absorb the moisture from the food. Nevertheless, we noticed an unexpected decrease in weight loss for 'Désirée' potato at the end of the storage. This decrease was unexpected because it occurred in the last days of

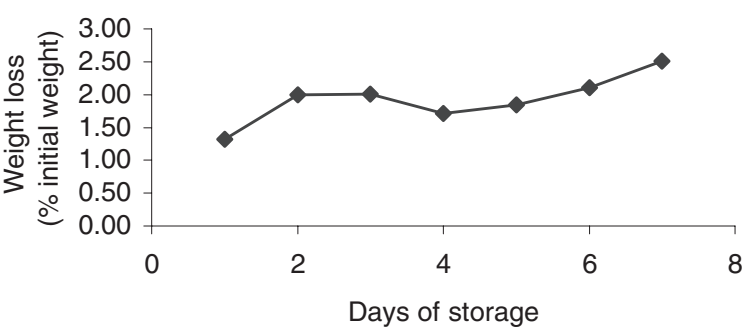

Figure 1 Weight loss (\%) of vacuum-packed 'Desirée' potato during storage at $6^{\circ} \mathrm{C}$ in the dark.

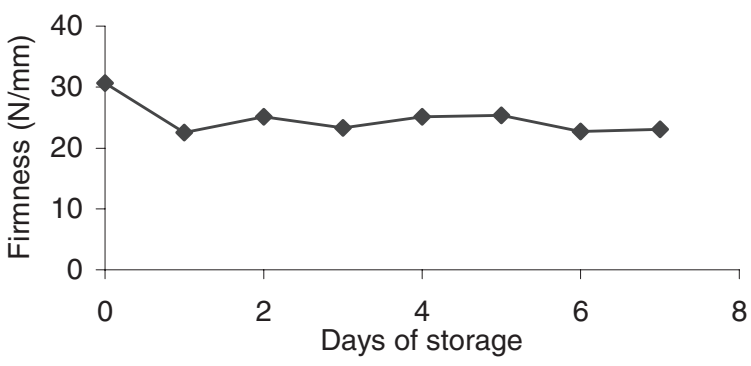

Figure 2 Firmness $(\mathrm{N} / \mathrm{m})$ of vacuum-packed 'Desirée' potato during storage at $6^{\circ} \mathrm{C}$ in the dark.

storage and it was not followed up by any change in firmness (Fig. 2).

Many researchers have indicated that the fundamental problem in the extension of shelf life of MP fruits and vegetables is the loss of firmness during storage and distribution. This results from the action of endogenous enzymes on the cell wall and growth of microorganisms (Rocha \& Morais 2001). A 25\% loss of firmness of 'Désirée' potatoes was observed after the first day, probably showing an increased enzymatic activity immediately after mechanical damage caused by processing operations. After that, firmness of 'Desirée' potatoes was constant during the remaining days of storage (Fig. 2).

According to Shetty et al. (1989), potato plastic wraps that decreased weight loss also tended to maintain tuber firmness. Firmness relates to turgidity of the potato and it is best maintained when water loss is reduced. The retention of firmness during vacuum storage of 'Desirée' potatoes must be related to the ability of the film used to decrease moisture loss and thereby maintain the integrity of the internal tuber tissue, including membranes. It should be also noted that the retention of firmness in the potatoes during the storage period is a further indication of the absence of significant microbial spoilage of the product (Chassery \& Gormley 1994). 


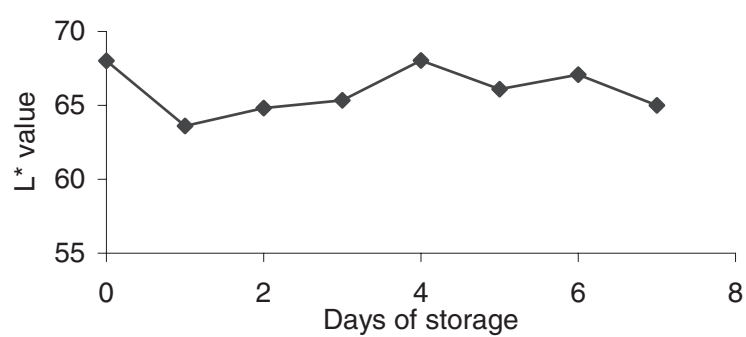

Figure $3 \mathrm{~L}^{*}$ value of vacuum-packed 'Desirée' potato during storage at $6^{\circ} \mathrm{C}$ in the dark. $\mathrm{L}^{*}$ indicates lightness.

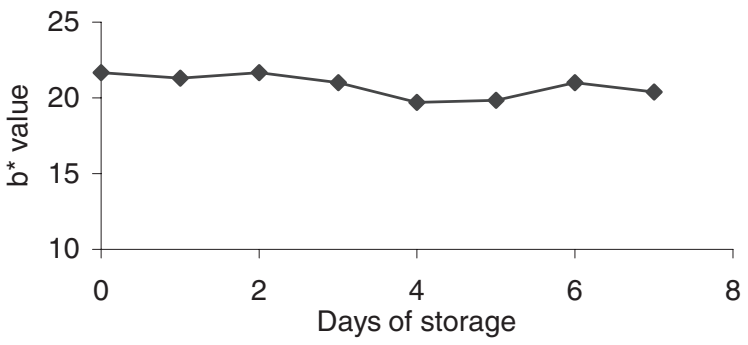

Figure 5 b* value of vacuum-packed 'Desirée' potato during storage at $6^{\circ} \mathrm{C}$ in the dark. $\mathrm{b} *$ indicates chromaticity on a blue to yellow axis.

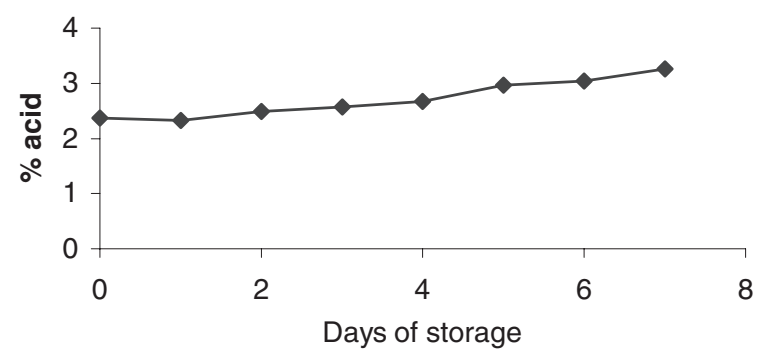

Figure 7 Acidity of vacuum-packed 'Desirée' potato during storage at $6^{\circ} \mathrm{C}$ in the dark.

\section{Colour assessment}

Oxidative browning of the surface of MP fruits and vegetables surface has been extensively reported. Most of the time it has been considered the limiting factor of shelf life of MP products (Carlin et al. 1990; El-Shimi 1993; Kim et al. 1993; Brecht 1995; Rocha \& Morais 2001). Colour changes of vacuum-packed 'Désirée' potatoes were not significant. A small decrease of lightness ( $\mathrm{L}^{*}$ value) was observed (Fig. 3). There is no significant change in $\mathrm{a}^{*}$ and $\mathrm{b}^{*}$ values during the storage (Figs 4 and 5).

\section{Titratable acidity and $\mathrm{pH}$}

A decrease in $\mathrm{pH}$ value of 'Désirée' potatoes was observed, which was obviously correlated to the

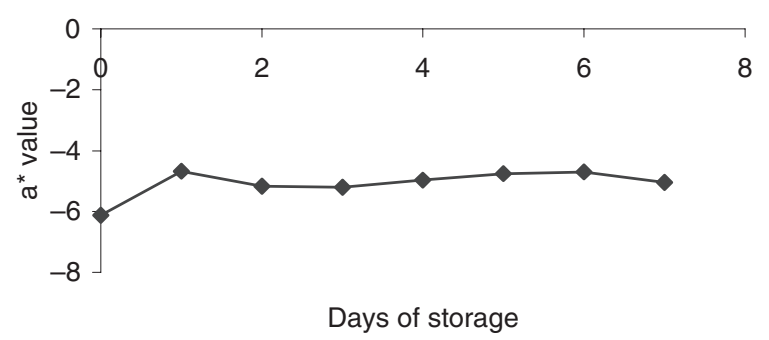

Figure 4 a* value of vacuum-packed 'Desirée' potato during storage at $6^{\circ} \mathrm{C}$ in the dark. $\mathrm{a}^{*}$ indicates chromaticity on a green to red axis.

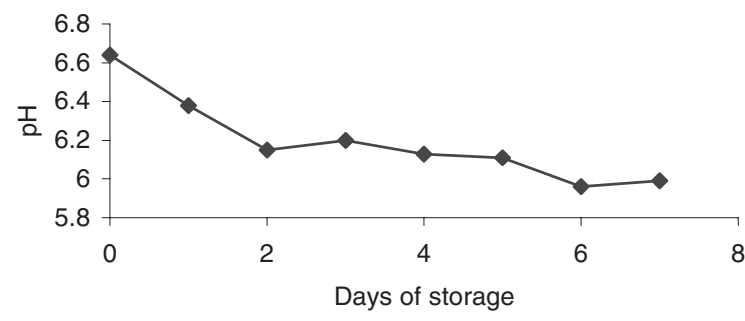

Figure $6 \mathrm{pH}$ value of vacuum-packed 'Desirée' potato during storage at $6^{\circ} \mathrm{C}$ in the dark.

increase observed in acidity (Figs 6 and 7), nevertheless those changes were not significant. This is desirable from the sensory point of view, because a variation in $\mathrm{pH}$ value would most certainly imply a negative change in flavour (Huxsoll \& Bolin 1989).

\section{Reducing sugars and soluble solids}

The sugar content of potatoes may vary from only trace amounts to as much as $10 \%$ of the dry weight of the tuber (Burton 1989). Sucrose, glucose and fructose are the main sugar compounds. Other sugars have been detected in potatoes but only in trace amounts. Many other plant tissues including potatoes often undergo a phenomenon known as low temperature sweetening after exposure to low temperatures (Coffin et al. 1987). Nevertheless, no changes were observed in the reducing sugar content of 'Désirée' potatoes after 7 days of storage. Small variations were noticed during storage with an increase on the first day of storage followed by a decrease at the third day (Fig. 8).

The initial increase might be related to the breakdown of high molecular weight compounds such as starch and hemicelullose into low molecular weight compounds such as simple sugars (Coseteng \& Lee 1987; Shetty et al. 1989). The following decrease from days $1-3$ might be the result of sugar consumption as a substrate in metabolic processes (Ackermann et al. 1992), which might have overcome the first effect. Nev- 


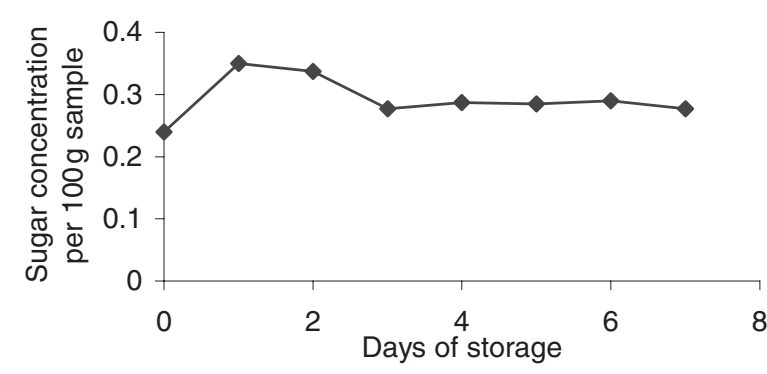

Figure 8 Reducing sugars of vacuum-packed 'Desirée' potatoes during storage at $6^{\circ} \mathrm{C}$ in the dark.

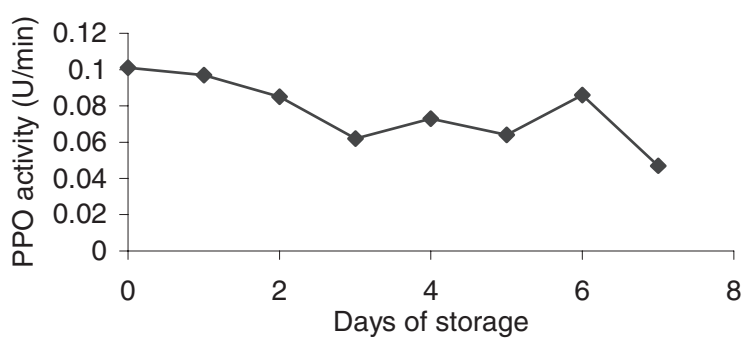

Figure 10 Polyphenoloxidase (PPO) activity of vacuumpacked 'Desirée' potato during storage at $6^{\circ} \mathrm{C}$ in the dark.

ertheless, those changes were not reflected in the soluble solids content: no significant changes were observed (Fig. 9).

\section{PPO activity}

PPO activity of 'Désirée' potatoes presented a small decrease during storage time (Fig. 10). Those results were in accordance with the colour assessment. Indeed, we noticed a small decrease of the $\mathrm{L}^{*}$ value which should be related to the development of browning. Heimdal et al. (1995) showed that enzymatic browning of lettuce by PPO was inhibited by moderate vacuum packaging in $80 \mu \mathrm{m}$ PE bags during about 3 weeks.

\section{Phenolic content}

The total phenolic compound of 'Désirée' potato was $0.6 \mu \mathrm{g}$ dopamine $/ 100 \mathrm{~g}$ of potato fresh weight. A small increase of total phenolic content for 'Désirée' potato was observed in the first day of storage immediately after minimal processing operations (Fig. 11).

Buescher et al. (1974) also reported that the phenolic content of snap beans pods increased after being broken. Ke \& Saltveit (1989) reported that wounding, by cutting the leaves or puncturing the tissue of iceberg lettuce, caused an increase of total soluble phenolic content, but those compounds were oxidized into brown substances in minutes by PPO. Howard \& Grif-

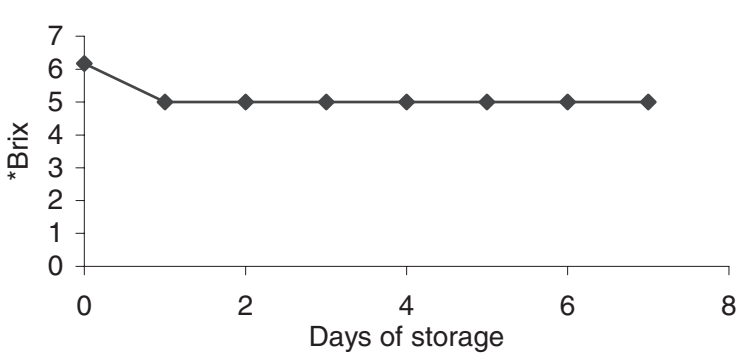

Figure 9 Soluble solids of vacuum-packed 'Desirée' potato during storage at $6^{\circ} \mathrm{C}$ in the dark.

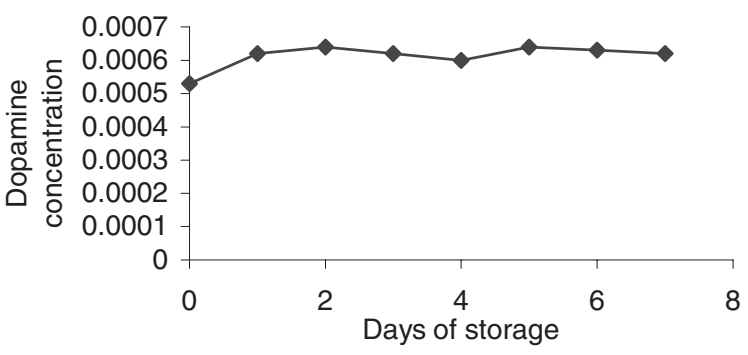

Figure 11 Total phenolic compound of vacuum-packed 'Desirée' potatoes during storage at $6^{\circ} \mathrm{C}$ in the dark.

fin (1993) reported an increase in total phenols of MP carrot sticks and associated this with a wound-induced increase in PAL (phenylalanine-amonia-lyase). Lattanzio et al. (1994) found that the phenolic content of artichoke heads was generally higher in mechanically damaged samples than in intact ones, although they had expected a reduction of phenolic content because of oxidative phenomena.

\section{Control}

The vacuum-packed potatoes stored at room temperature became brown after 2 days and after 4 days they had deteriorated to the point they were inedible.

The peeled potatoes stored under refrigeration became brown since the first day of storage and after 4 days were completely inedible.

As can be seen, the keeping quality of vacuumpacked potatoes is extremely high and presents a number of obvious advantages to food service operations. This product is 'fresh-like' and presents high convenience and speed with which meals can be prepared. This is also very appealing to the consumer.

\section{Conclusion}

Vacuum packaging appeared to be an effective package for protection of the quality of MP 'Desirée' potatoes. The shelf life of MP potatoes may be extended to 
1 week under refrigerated storage by using vacuum packaging systems.

The main quality parameters are constant during the storage. The 'fresh-like' quality of potatoes was effectively preserved by a $100-\mu \mathrm{m}$ PE/PA bag, an outer PA layer and an inner PE layer. The PA is responsible for mechanical strength and impermeability to $\mathrm{O}_{2}$ and other gases. PE is co-extruded for its water and vapour impermeability. PPO activity was greatly inhibited by vacuum packaging using $100 \mu \mathrm{m}$ PE bags.

Because the absence of air in vacuum packaging may favour the growth of anaerobic pathogens, such as Clostridium botulinum, it would be of extremely importance to develop the microbiological evaluation.

\section{Acknowledgements}

The authors acknowledge the firm Interbatata from Lourinhã, Portugal for the supply of the potatoes and information about the processing conditions and the crop.

\section{References}

Ackermann J, Fischer M, Amado R (1992). Changes in sugars, acids, and amino acids during ripening and storage of apples (Cv. Glockenapfel). Journal of Agricultural and Food Chemistry 40:1131-4.

Ahevenainen RT, Hurme EU, Hagg M, Skytta EH, Laurila EK (1998). Shelf life of prepeeled potato cultivated, stored, and processed by various methods. Journal of Food Protection 61:591-600.

Brecht JK (1995). Physiology of lightly processed fruits and vegetables. Hortscience 30:18-21.

Brody A (1989). Introduction. In: Controlled/modified Atmospherelvacuum Packaging of Foods (ed. A Brody), pp. 116. Food and Nutrition Press, Inc.: Trumbull, CT.

Buescher RW, Reitmeier C, Sistrunk WA (1974). Association of phenylalanina amonia lyase, catecholase, peroxidase and total phenolic content with brown-end discoloration of snap bean pods. Hortscience 9:585.

Burton WG (1989). The distribution and composition of the dry matter in the potato tuber. In: The Potato (ed. PM Harris), 3rd edn, p. 286. Longman: Harlow.

Carlin F, Nguyen-The C, Varoquaux P (1990). La conservation des produits de la 4ème gamme. Actualites des Industries Alimentaires et Agro-Alimentaires 10:931-44.

Chassery S, Gormley TR (1994). Quality and shelf life of prepeeled vacuum packed potatoes. Farm \& Food July/ December:30-2.

Coffin RH, Yada RY, Parkin KL, Grodzinski B, Stanley DW (1987). Effect of low temperature storage on sugar concentrations and chip color of certain processing potato cultivars and selections. Journal of Food Science 52:639-45.

Coseteng MY, Lee CY (1987). Changes in apple polyphenoloxidase and polyphenol concentration in relation to degree of browning. Journal of Food Science 52:985-9.
El-Shimi N (1993). Control of enzymatic browning in apple slices by using ascorbic acid under different conditions. Plant and Foods for Human Nutrition 43:71-6.

Folin D, Ciocalteau V (1927). On tyrosine and tryptophane determinations in proteins. Journal of Biology and Chemistry 73:627-50.

Gorris LGM, Peppelenbos HW (1992). Modified atmosphere and vacuum packaging to extend the shelf life of respiring food products. Horttechnology 2:303-9.

Heimdal H, Kuhn BF, Poli L, Larsen LM (1995). Biochemical changes and sensory quality of shredded and MA-packaged Iceberg lettuce. Journal of Food Science 60:1265-8, 1276.

Hintlian CB, Hotchkiss JH (1986). The safety of modified atmosphere packaging: a review. Food Technology 12:706.

Howard LR, Griffin LE (1993). Lignin formation and surface discoloration of MP carrot sticks. Journal of Food Science 58:1065-7.

Huxsoll CC, Bolin HR (1989). Processing and distribution alternatives for MP fruits and vegetables. Food Technology 2:124-8.

Johnson FB, Hoffman I, Petrasovits A (1968). Distribution of mineral constituent and dry matter in the potato tuber. American Potato Journal 45:287-9.

Kader AA (1982). Proper units for firmness and abscission force data. Hortscience 17:707.

Ke D, Saltveit ME (1989). Wound induced ethylene production phenolic metabolism and susceptibility to russet spotting in iceberg lettuce. Physiology Plant 76:412-18.

Kim DM, Smith NL, Lee CY (1993). Quality of MP apple from selected cultivars. Journal of Food Science 58:1115-17.

Krause MV, Mahan LK (1985). Dietetic necessities recommended and adequate diet. In: Food, Nutrition and Diet Therapy (eds MA Krause \& LK Mahan), pp. 215-46. W.B. Saunders Company: New York.

Langdon TT (1987). Prevention of browning in prepared potatoes without the use of sulfiting agents. Food Technology 41:64-7.

Lattanzio V, Cardinali A, Palmieri S (1994). The role of phenolics in the postharvest physiology of fruits and vegetable: browning reaction and fungal diseases. Italian Journal of Food Science 1:3-22.

Laurila EK, Hurme EU, Ahvenainen RJ (1998). Shelf life of sliced raw potatoes of various cultivar varieties. Journal of Food Protection 61:1363-71.

Macrae R, Robinson RK (1993). Potatoes and related crops. In: Encyclopaedia of Food Science, Food Technology and Nutrition (eds R Macrae, RK Robinson \& MJ Sadler), pp. 3672-86. Academic Press Inc: San Diego, CA.

Martens T (1995). Current status of sous vide in Europe. In: Principles of Modified-Atmosphere and Sous Vide Product Packaging (eds JM Farber \& KL Dods), pp. 37-68. Technomic Publishing Inc: Lancaster.

Mastrocola D, Lerici CR (1991). Colorimetric measurements of enzymatic and non-enzymatic browning in apple purees. Italian Journal of Food Science 3:219-29.

Monsalve-Gonzalez A, Barbosa-Cánovas GV, Cavalieri RP, McEvily AJ, Iyengar R (1993). Control of browning during storage of apple slices preserved by combined methods. 4Hexylresorcinol as antibrowning agent. Journal of Food Science 58:826.

O'Beirne D, Ballantyne A (1987). Some effects of modified atmosphere packaging and vacuum packaging in combination with antioxidants on quality and storage life of chilled 
potato strips. International Journal of Food Science and Technology 22:512-23.

RDA (1989). Recommended Dietary Allowances. Subcommittee on the tenth edition of the RDAs. Food and Nutrition Board. Commission on Life Sciences. National Research Council. National Academy Press: Washington, DC.

Reyes-Moreno C, Parra-Inzunca MA, Milan-Carrillo J, Zazueta-Niebla JA (2001). A response to surface methodology approach to optimise pretreatments to prevent enzymatic browning in potato (Solanum tuberosum L) cubes. Journal of the Science of Food and Agriculture 82:69.

Rocha AMCN, Morais AMB (2001). Characterization of PPO extracted from 'Jonagored' apple. Food Control 12:85-90.

Sapers GM, Miller RL (1992). Enzymatic browning control in potato with ascorbic acid-2-phosphate. Journal of Food Science 57:1132-5.
Shetty KK, Kochan WJ, Dwelle RB (1989). Use of heat-shrinkable plastic film to extend shelf life of 'Russet Burbank' potatoes. Hortscience 24:643-6.

Singleton AD, Rossi JA Jr (1965). Colorimetry of total phenolics with phosphomolybdic-phosphotungstic acid reagents. American Journal of Enology and Viticulture 16:144-58.

Vamos-Vigyàzò L (1981). Polyphenoloxidase and peroxydase in fruits and vegetables. Critical Reviews in Food Science and Nutrition 9:49-127.

Varoquaux PJA, Nguyen-The C (1994). Vacuum processing: a new concept for pre-cooked fruit and vegetables. Proceedings. Food Science and Technology Today 8:42-9.

Whitaker JR (1994). Effect of substrate concentration on rates of enzyme-catalysed reactions. In: Principles of Enzymology, pp. 167-99. Marcel Decker Inc.: New York. 